\title{
Survey of infection control resources and services in outpatient settings in China
}

\author{
F Qiao*, W Huang, Y Wang, Z Zong \\ From 3rd International Conference on Prevention and Infection Control (ICPIC 2015) \\ Geneva, Switzerland. 16-19 June 2015
}

\section{Objectives}

This study was conducted to assess the status of infection control resources and services in outpatient settings in China.

\section{Methods}

A questionnaire on the structure, organization, and resources for infection surveillance and control work was designed and sent to 420 hospitals distributed in 5 provinces in China. The questionnaire also included the jobs that have carried out in these hospitals. Epidata 3.1 and SPSS 17.0 were used for data entry and analyze.

\section{Results}

A total of 416 (99.0\%) hospitals responded, including $115(27.6 \%)$ tertiary hospitals, 131 (31.5\%) second-class hospitals, 39 (9.4\%) traditional Chinese Medicine hospitals, 38 (9.1\%) women's and children's hospitals, 30 (7.2\%) private hospitals, $50(12.0 \%)$ community health service centers and 13 (3.2\%) other type hospitals. $94.7 \%$ of the participating hospitals have set up an infection control team in outpatient settings, $94.5 \%$ of them had an surveillance and control program, but only $75.5 \%$ outpatient settings arranged an link nurse to do infection control job. In terms of hand hygiene, 372 (89.4\%) hospitals had hand sinks and $343(82.5 \%)$ provided alcohol based hand rub in every clinic rooms. Only 76 (18.3\%) outpatient settings offered hand hygiene equipment for patients in the waiting room. For personal protective equipment, 290 (69.7\%) hospitals provided gloves for health care workers (HCWs), and only $270(64.9 \%)$ and 181 (43.5\%) settings afforded surgical mask and respirator for health care workers respectively. 400 (96.2\%) hospitals gave HCWs education or training on infection control. Observe hand hygiene compliance $(348,83.7 \%)$ and supervise disinfection of

\footnotetext{
Infection Control Department, West China Hospital, Sichuan University,
} Chengdu, China

(c) 2015 Qiao et al; licensee BioMed Central Ltd. This is an Open Access article distributed under the terms of the Creative Commons Attribution License (http://creativecommons.org/licenses/by/4.0), which permits unrestricted use, distribution, and reproduction in any medium, provided the original work is properly cited. The Creative Commons Public Domain Dedication waiver (http:// creativecommons.org/publicdomain/zero/1.0/) applies to the data made available in this article, unless otherwise stated. health care surroundings $(330,79.3 \%)$ were the main infection control activity carried out in these settings, only a few settings did another infection work such as surveillance for surgical site infection $(9.6 \%)$ or catheter related bloodstream infection (9.1\%).

\section{Conclusion}

As a developing country, resources for infection prevention and control in outpatient settings were not enough in China. Only a few hospitals did health care associated infection surveillance and control work besides education. More needs to be done to improve the current situation of infection prevention and control in China.

\section{Disclosure of interest}

None declared.

Published: 16 June 2015

doi:10.1186/2047-2994-4-S1-P249

Cite this article as: Qiao et al:: Survey of infection control resources and services in outpatient settings in China. Antimicrobial Resistance and Infection Control 2015 4(Suppl 1):P249.

Submit your next manuscript to BioMed Central and take full advantage of:

- Convenient online submission

- Thorough peer review

- No space constraints or color figure charges

- Immediate publication on acceptance

- Inclusion in PubMed, CAS, Scopus and Google Scholar

- Research which is freely available for redistribution 